\title{
Molecular diagnosis of benzimidazole resistance in Haemonchus contortus in sheep from different geographic regions of North India
}

\author{
S. Chandra ${ }^{1}$, A. Prasad $^{1}$, M. Sankar ${ }^{2}$, N. Yadav ${ }^{1}$ and S. Dalal ${ }^{1}$ \\ 1. Division of Veterinary Parasitology, Indian Veterinary Indian Veterinary Research Institute, \\ Izatnagar - 243 122, Uttar Pradesh, India; 2. Tropical Animal Health and Production, Indian Veterinary Research \\ Institute, Mukteswar, Uttarakhand, India \\ Correspondence author: A. Prasad, email: drarvindivri@rediffmail.com \\ Received: 06-03-2014, Revised: 09-04-2014, Accepted: 16-04-2014, Published online: 20-05-2014
}

doi: 10.14202/vetworld.2014.337-341 How to cite this article: Chandra S, Prasad A, Sankar M, Yadav N and Dalal S (2014) Molecular diagnosis of benzimidazole resistance in Haemonchus contortus in sheep from different geographic regions of North India, Veterinary World 7(5): 337-341.

\begin{abstract}
Aim: To monitor the benzimidazole resistance in Haemonchus contortus in sheep from different agro climatic zones of India reared in extensive or intensive managemental conditions.

Materials and Methods: Faecal materials were collected from sheep from organized as well as private farms located in Rohilkhand region, Bundelkhand region, and Eastern Utter Pradesh. Larvae were obtained by coproculture and identified as $\mathrm{L}_{3}$ of Haemonchus contortus. Exsheathment of larvae was done by incubating them in $180 \mu$ l of sodium hypochlorite for 5-20 minutes. Genomic DNA was isolated from single larvae and amplification of $\beta$-tubulin of Haemonchus contortus was done by primary and nested PCR. PCR-RFLP was done with RsaI enzyme for species identification. Genotyping was done by Allele specific PCR using Nested PCR product as template and resulting fragments were separated by gel electrophoresis in a $1.5 \%$ agarose gel in TAE buffer.
\end{abstract}

Results: Species was confirmed as H. contortus by PCR-RFLP which shows three fragments at $440 \mathrm{bp}, 190 \mathrm{bp}$, and $150 \mathrm{bp}$. From Rohilkhand region out of 30 larvae, 19 (63\%) were homozygous resistant (RR), $6(20 \%)$ were homozygous susceptible (SS), and $5(17 \%)$ were heterozygous (RS). From Bundelkhand $34(85 \%)$ were RR, $4(10 \%)$ were SS, and $2(5 \%)$ were RS out of 40 larvae screened. From Eastern UP (Jaunpur and Varanasi) 30 larvae each from Jaunpur and Varanasi were genotyped;larvae from Jaunpur revealed 53\% RR, 27\% SS, and 20\% RS whereas larvae from Varanasi genotyped showed $57 \%$ RR, $17 \%$ SS, and $26 \%$ RS.

Conclusion: Due to indiscriminate use of Benzimidazole group of drugs in organized and private farms, resistance to this group of drugs is increasing at the field level.

Keywords: $\beta$-tubulin, allele specific PCR, benzimidazole resistance, Haemonchus contortus.

\section{Introduction}

Benzimidazole group of anthelmintics are widely used for control of Haemonchosis in sheep due to their high therapeutic index and absence of toxic residues in milk and meat [1]. Benzimidazole (BZ) exhibit the anthelmintic activity by binding to $\beta$-tubulin which interferes with polymerization of the microtubule. Resistance to $\mathrm{BZ}$ is correlated with a conserved mutation at amino acid 200 in $\beta$-tubulin in isotype-1 with Phenylalanine being replaced by Tyrosine [2].

The diagnosis of $\mathrm{BZ}$ resistance in a worm population of Trichostrongyle parasites was based until now on the estimation in vitro of the lethal dose 50 $\left(\mathrm{LD}_{50}\right)$ on eggs (Egg hatch assay), on larvae (Larval development assay), or in vivo of the egg reduction in faecal sample after BZ treatment (FECRT) $[3,4,5]$. These methods have proved their efficacy but can only detect $\mathrm{BZ}$ resistant worm population when more than $25 \%$ of the parasites are BZ resistant [6].

Benzimidazole resistance in Trichostrongylid nematodes has been reported by many researchers.

Copyright: The authors. This article is an open access article licensed under the terms of the Creative Commons Attribution License (http://creativecommons.org/licenses/by/2.0) which permits unrestricted use, distribution and reproduction in any medium, provided the work is properly cited.
First report of Thiabendazole resistance in sheep in India was from Rishikesh (Uttarakhand) [7]. Other reports are from Himanchal Pradesh from goats [8], Uttar Pradesh, Uttarakhand [9-13], Rajasthan [14], and South India $[15,16]$.

In current study Allele-specific Polymerase Chain Reaction (AS-PCR) was employed to detect BZ resistance in larval population of Haemonchus contortus of sheep origin, and susceptible, resistant, and heterozygous population was genotyped.

\section{Materials and Methods}

Ethical approval: Adequate measures were taken to minimize pain or discomfort to animals while taking samples per-rectally. Experiments were carried out in accordance with the guidelines laid down by the Institutional ethics committee and in accordance with local laws and regulations.

Study area: Faecal samples were collected from organised and private farms per-rectally from sheep. These farms were located in Rohilkhand region (Bareilly), Bundelkhand (Jhansi), and Eastern UP (Jaunpur and Varanasi).

Harvesting of $\mathrm{L}_{3}$ larvae of $\boldsymbol{H}$. Contortus: $\mathrm{L}_{3}$ of Heamonchus 
were obtained from coproculture of sheep faeces from areas which had history of Haemonchus infection previously and larvae were identified [17]. The characters taken as criteria for correct identification of larvae of Haemonchus were length of larvae including sheath, anterior end of larvae, number and shape of intestinal cells and distance between tail of $\mathrm{L}_{3}$ and sheath.

Genomic DNA extraction from larvae: Larvae were collected from culture and washed 3-4 times with distilled water. Approximately 200 larvae were exsheathed by incubation for 5-20 minutes in a petridish containing $4 \mathrm{ml}$ of larval suspension and $180 \mu \mathrm{l}$ of Sodium hypochlorite (aqueous solution, 4\% active chlorine). Single larva was removed with $2 \mu 1$ of suspension and killed by placing in a micro tube at $-20^{\circ} \mathrm{C}$ for $20 \mathrm{~min}$. DNA was extracted by adding $5 \mu 1$ extraction buffer ( $1 \mathrm{mM}$ Tris-HCl, $0.1 \mathrm{mM}$ EDTA and 5 $\mathrm{mg} / \mathrm{ml}$ proteinase $\mathrm{K}$ ) and incubating tubes at $50^{\circ} \mathrm{C}$ for overnight. Proteinase $\mathrm{K}$ was inactivated by incubation at $95^{\circ} \mathrm{C}$ for 20 minutes [18].

Oligonucleotide primers: Oligonucleotide primers $\left(\mathrm{P}_{1}\right.$ to $\mathrm{P}_{7}$ ) were synthesised from published sequence [19]. $\mathrm{P}_{1}-5^{\prime}$ GGC AAG TAT GTC CCA CGT GC 3, $\mathrm{P}_{2}-5^{\prime}$ 'GAT CAG CAT TCA GCT GTC CA 3' P 3 - 5'GGAACAATG

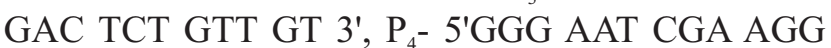
CAG GTC GT 3' $\mathrm{P}_{5}-5^{\prime}$ 'GGAACG ATG GAC TCC TTT CG 3', $\mathrm{P}_{6}-5^{\prime}$ CTG GTA GAG AAC ACC GAT GAA ACA TA 3', $\mathrm{P}_{7}-5$ ' ATA CAG AGC TTC GTT GTC AAT ACAGA3',

\section{Amplification of $\beta$-tubulin}

Primary polymerase chain reaction (PCR): PCR was carried out in thin wall PCR tubes in $25 \mu 1$ reaction volume. Genomic DNA from third stage larvae was used as template for amplification of $\beta$-tubulin. The PCR mixture consisted of $5 \mu$ lof lysate as template, 20 pmol of each primer $\left(\mathrm{P}_{1}\right.$ and $\left.\mathrm{P}_{2}\right), 1 \mathrm{mM} \mathrm{MgCl} \mathrm{ma}_{2}, 100 \mu \mathrm{M}$ of each dNTPs, and $2.5 \mu$ l of $10 \mathrm{x}$ Taq DNA polymerase buffer and $1 \mathrm{U}$ of Taq DNA polymerase (Fermentas, Germany). The volume of the reaction was made up to $25 \mu 1$ with autoclaved milli-Q water. Polymerase chain reaction was performed using PTC-200 with the following conditions.

Initial Denaturation at $94^{\circ} \mathrm{C}$ for two minutes was followed by 20 cycles each at $94^{\circ} \mathrm{C}$ for $55 \mathrm{~s}, 57^{\circ} \mathrm{C}$ for 55 $\mathrm{s}$ and $72^{\circ} \mathrm{C}$ for $55 \mathrm{~s}$. This was followed by $10 \mathrm{~min}$ final extension at $72^{\circ} \mathrm{C}$. The PCR amplicons were used as template for nested PCR.

Nested PCR: The $\beta$-tubulin PCR amplicons were used as template for nested PCR. The PCR mixture consisted of $3 \mu 1$ of template ( $\beta$-tubulin PCR product) 20 pmol of $\mathrm{P}_{3}$ and $\mathrm{P}_{4}$ primers, $100 \mu \mathrm{M}$ of each dNTPs, 2 $\mathrm{mM}$ of $\mathrm{MgCl}_{2}, 2.5 \mu 1$ of $10 \mathrm{x}$ Taq DNA polymerase buffer and $1 \mathrm{U}$ of Taq DNA polymerase. The volume of reaction was made up to $25 \mu 1$ with autoclaved milli-Q water. PCR was performed in PTC-200 with conditions as similar as $\beta$-tubulin amplification.

Restriction Fragment length polymorphism (RFLP) with RsaI enzyme: $10 \mu$ l of the amplified nested product was digested with the restriction enzyme $R s a I$ for species identification. The restriction enzyme digestion was performed in waterbath for 4 hours at $37^{\circ} \mathrm{C}$ and, resulting fragments were separated by electro-phoresis on a $2.5 \%$ agarose gel and their lengths used for species identification [19].

AS-PCR: Two aliquots $(1.5 \mu \mathrm{l})$ of the $\left(\mathrm{P}_{3}-\mathrm{P}_{4}\right)$ nested product were used to determine the resistance of larvae against BZ group of drugs. The system was divided into two mixes, each containing two non-specific primers $\left(\mathrm{P}_{4}\right.$ and $\left.\mathrm{P}_{5}\right)$ and one allele-specific primer. Each reaction generated one allele specific and one non allele specific fragments. The PCR mixture volume is $25 \mu 1.1 .5 \mu 1$ of nested product used as template for amplification of allele specific PCR with 10pmol of $\mathrm{P}_{4}$ $\& \mathrm{P}_{5}$,20pmol of $\mathrm{P}_{6}$ in one mix and $\mathrm{P}_{7}$ in another mix, 1 $\mathrm{mM} \mathrm{MgCl}{ }_{2}, 80 \mu \mathrm{M}$ of each dNTPs, $2.5 \mu 1$ of Taq DNA polymerase buffer and $1 \mathrm{U}$ of Taq DNA polymerase. The volume of the mixture was made up to $25 \mu 1$ with autoclaved milli-Q water.

PCR was performed with following conditions: Initial denaturation at $94^{\circ} \mathrm{C}$ for 2 minutes was followed by 30 cycles each at $94^{\circ} \mathrm{C}$ for $55 \mathrm{~s}, 55^{\circ} \mathrm{C}$ for $55 \mathrm{~s}$ and $72^{\circ} \mathrm{C}$ for $55 \mathrm{~s}$. This was followed by $10 \mathrm{~min}$ final extension at $72^{\circ} \mathrm{C}$. The resulting fragments were separated by gel electrophoresis in a $1.5 \%$ agarose gel in TAE (1x) buffer for 1 hour at constant voltage $(100 \mathrm{~V})$.

Statistical analysis: Statistical analysis was performed using the Chi test for analysis [20]. The values that were below $\mathrm{P}<0.05$ were considered as significant.

\section{Results}

Identification of Haemonchus larvae: The anterior end of larvae was bullet shaped intestinal cells were 16 in number and rectangular in shape. The tail of the sheath was showing kink in the tail just after the tail of the larva proper (Figure-1 and 2).

Amplification of $\boldsymbol{\beta}$-tubulin gene of $\boldsymbol{H}$. Contortus: The primary PCR size of genomic DNA isolated from pooled larvae of $H$. contortus was $840 \mathrm{bp}$ (Figure-3). Nested PCR amplified approxi-mately 774 bp product (Figure-4). In PCR-RFLP the expected fragments were obtained from third stage larvae of $H$. contortus. One internal fragment of $440 \mathrm{bp}$, low intense $190 \mathrm{bp}$ and $150 \mathrm{bp}$ were confirmed the species as $H$. contortus (Figure-5). In Allele specific PCR the size of the specific bands were susceptible allele specific gene at $550 \mathrm{bp}$, resistant allele specific gene at $250 \mathrm{bp}$ non allele specific gene at $750 \mathrm{bp}$ (Figure-6).

The extent of resistance was found to increase at field level (Table-1). From Rohilkhand region 30 larvae were analyzed of which 19 (0.63) were homozygous resistant (rr), 6 (0.20) homozygous susceptible (SS) and 5 (0.17) heterozygous (rS). From Bundelkhand 


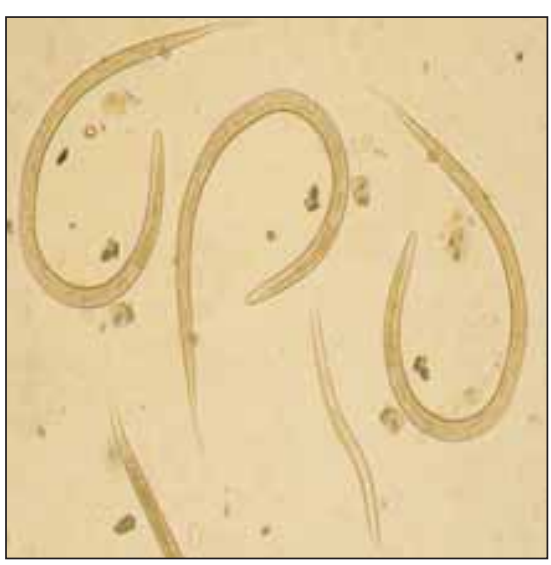

Figure-1: $L_{3}$ larvae of $H$. contortus

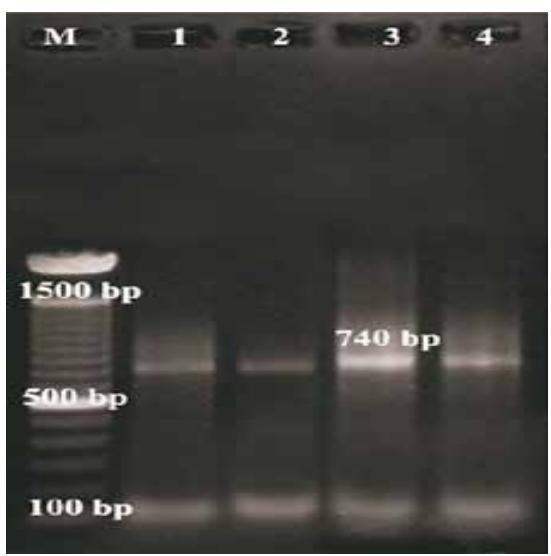

Figure-4: Nested PCR from $\mathrm{L}_{3}$ of $\mathrm{H}$. contortus, Lane M : 100 bp DNA ladder, Lane 1 : Rohilkhand strain, Lane 2 : Jhansi strain, Lane 3 : Jaunpur strain, Lane 4 : Varanasi strain

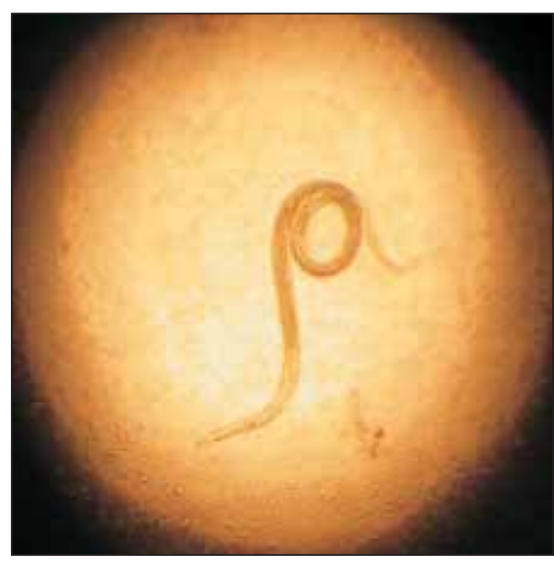

Figure-2: Exsheathed $\mathrm{L}_{3}$ of $H$. contortus

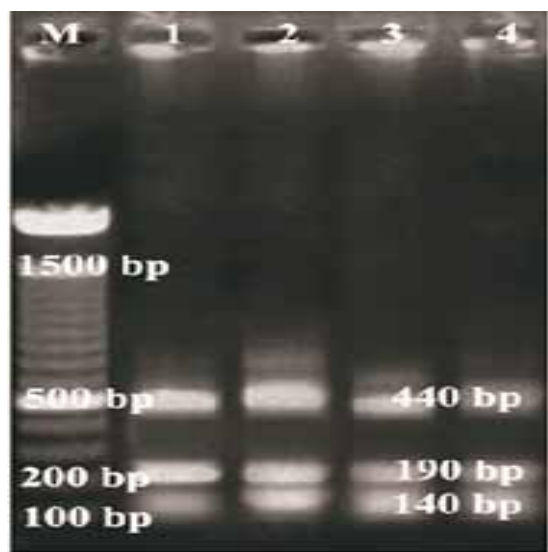

Figure-5: RFLP with RSa1 enzyme of $\mathrm{L}_{3}$ H. contortus, Lane M: 100 bp DNA ladder, Lane 1 : Rohilkhand strain, Lane 2 : Jhansi strain, Lane 3 : Jaunpur strain, Lane 4 : Varanasi strain

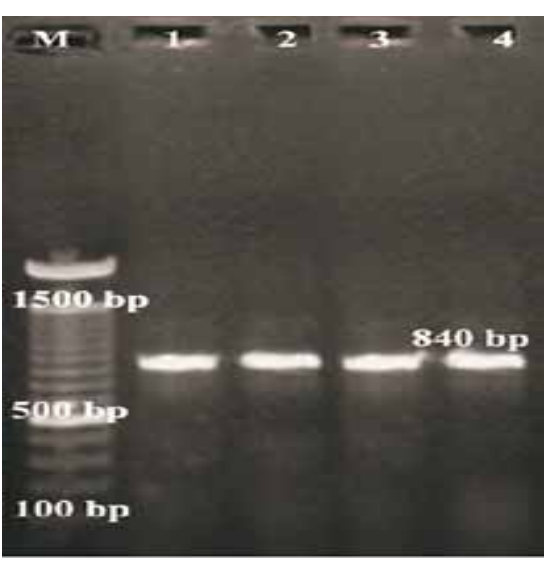

Figure-3: Standard PCR from pooled larvae of $H$. contortus, Lane M : 100 bp DNA ladder, Lane 1 : Rohilkhand strain, Lane 2 : Jhansi strain, Lane 3 : Jaunpur strain, Lane 4 : Varanasi strain

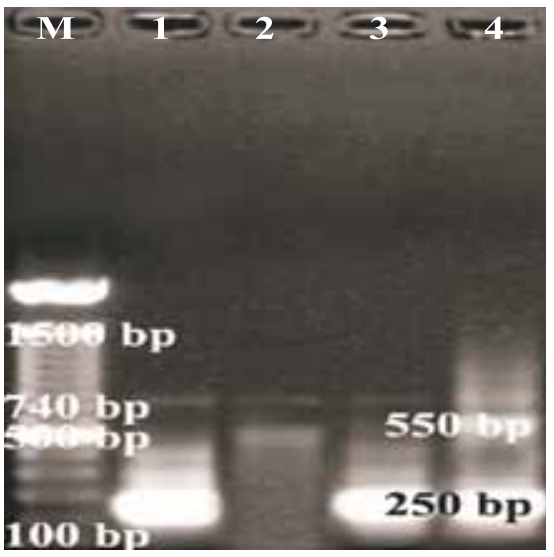

Figure-6: AS PCR of $\mathrm{L}_{3}$ of $H$. contortus, Lane M : 100 bp DNA ladder, Lane 1: Rohilkhand strain, Lane 2 : Jhansi strain, Lane 3 : Jaunpur strain, Lane 4 : Varanasi strain

Table-1: Genotyping of larvae of $H$. contortus

\begin{tabular}{|c|c|c|c|c|c|c|c|}
\hline \multirow[t]{2}{*}{ Location } & \multirow[t]{2}{*}{ Host } & \multirow[t]{2}{*}{ No. of $\mathrm{L}_{3}$ larvae } & \multicolumn{3}{|c|}{ Genotypic frequency } & \multicolumn{2}{|c|}{ Allelic frequency } \\
\hline & & & $\begin{array}{l}\text { Homozygous } \\
\text { Resistant (RR) }\end{array}$ & $\begin{array}{c}\text { Homozygous } \\
\text { susceptible (SS) }\end{array}$ & $\begin{array}{l}\text { Heterozygous } \\
\text { (RS) }\end{array}$ & $\begin{array}{l}\text { Resistant } \\
\text { (R) }\end{array}$ & $\begin{array}{l}\text { Susceptible } \\
\text { (S) }\end{array}$ \\
\hline $\begin{array}{l}\text { Rohilkhand } \\
\text { (organized farm) } \\
\text { Bundelkhand }\end{array}$ & Sheep & 30 & $19(0.63)$ & $6(0.20)$ & $5(0.17)$ & 0.73 & 0.27 \\
\hline $\begin{array}{l}\text { (organized farm) } \\
\text { Jaunpur }\end{array}$ & Sheep & 40 & $34(0.85)$ & $4(0.10)$ & $2(0.05)$ & 0.88 & 0.12 \\
\hline (Private farm) & Sheep & 30 & $16(0.53)$ & $8(0.27)$ & $6(0.20)$ & 0.63 & 0.37 \\
\hline Varanasi (Private farm) & Sheep & 30 & $17(0.57)$ & $5(0.17)$ & $8(0.26)$ & 0.70 & 0.30 \\
\hline
\end{tabular}

region (Jhansi) 40 larvae from sheep were analyzed and result showed a high degree of resistance in organized farm of Jhansi of which more than $75 \%$ larval population showed resistance (rr). From Eastern U.P. larvae were analyzed from Jaunpur and Varanasi. 30 larvae from sheep from Jaunpur were analyzed of which $16(0.53)$, homozygous resistant (rr), $8(0.27)$ homozygous susceptible (SS), $6(0.20)$ heterozygous $(\mathrm{rS})$. Larvae from sheep of Varanasi were showing more resistance.

\section{Discussion}

Benzimidazole resistance in India is a wide spread problem interfering with control of gastrointestinal nematodiasis in field as well as organised farm. Although, some workers have previously reported resistance employing conventional techniques. Very few reports are available on the application of molecular technique AS-PCR which can be very easily applied to $\mathrm{L}_{3}$ larvae obtained from coproculture of faeces of infected animals not responding to this group of anthelmintic.

During the present study larval $\left(\mathrm{L}_{3}\right)$ population from different regions of Uttar Pradesh were genotyped. These regions were Rohilkhand, Bundelkhand, Jaunpur and Varanasi which are under different agro climatic zones of Uttar Pradesh. In nested PCR, the amplified 
product was of $774 \mathrm{bp}$. In RFLP, for species identification DNA fragments were of $440 \mathrm{bp}, 190 \mathrm{bp}$, and $150 \mathrm{bp}$ when RSa1 enzyme was utilized. The fragments confirmed the larvae belonging to $H$. contortus. Our results of nested PCR are similar to earlier study [19] who also found DNA fragments of $441 \mathrm{bp}, 190 \mathrm{bp}$ and 155 bp with same enzyme in RFLP. In nested PCR, product size was $774 \mathrm{bp}$ which is slightly different from earlier study [19]. In AS-PCR specific bands showing susceptibility to BZ was of $550 \mathrm{bp}$ and resistance specific gene was of $250 \mathrm{bp}$ and non specific gene at $750 \mathrm{bp}$. Since the genes are conserved in H. contortus it was found that the product size of AS-PCR were similar in larval samples collected from different regions. Our results are further confirmed by similar observation on larval population for detection of point mutation involved in BZ resistance applying AS-PCR [19]. The fragments generated by AS-PCR were similar to previous workers $[11,12,13,16,19]$.

Genotypic frequency of larvae with reference to homozygous resistant (RR), homozygous susceptible (SS) and heterozygous (RS) differed in different regions. RR population was maximum ( $85 \%$ ) in organised farm from Bundelkhand region from sheep. It was followed by organised farm in Rohilkhand region (63\%). In private farms, RR population showed increasing trend which varied $53 \%$ (Jaunpur) to $57 \%$ (Varanasi). SS population varied from $10 \%$ (Bundelkhand) to $20 \%$ (Rohilkhand). In private farms, SS population varied from $17 \%$ (Varanasi) to $27 \%$ (Jaunpur). RS population in organised farms varied from 5\% (Bundelkhand) to $17 \%$ (Rohilkhand). In private farms RS population varied from $20 \%$ (Jaunpur) to $30 \%$ (Varanasi).

The results indicated that in organized farms, due to frequent use of BZ group of drugs, RR population is increasing and susceptible population is decreasing. RS population also has decreased drastically and in due course of time complete resistant population may develop unless suitable measures to avoid anthelmintic resistance is taken up applying principle of grazing management and TST applying FAMACHA. Similar studies on BZ resistance has also been conducted utilizing RFLP-PCR and it was found 68\% RR, 17\% RS and 15\% SS larvae out of 54 larvae [21]. The allelic frequency for gene for ' $r$ ' was 0.77 and gene for susceptibility 'S' 0.23 . In the present study allelic frequency of ' $r$ ' gene varied from 0.63 (Jaunpur) to 0.88 (Bundelkhand) where as for 'S' gene it was 0.12 (Bundelkhand) to 0.37 (Jaunpur). Our results indicated that allelic frequency for resistant gene is increasing in organised farm in Bundelkhand region followed by Rohilkhand.

\section{Conclusion}

Molecular method (AS-PCR) is a quick and reliable method for diagnosis of Benzimidazole resistance at early stage of development of resistance in $H$. contortus. Prevalence of resistance in $H$. contortus has been detected against Benzimidazole group of drugs in Rohilkhand, Bundelkhand (Jhansi), and Eastern U.P. (Jaunpur, Varanasi). Benzimidazole resistance from
Bundelkhand and Eastern U.P. has been recorded for the first time from both farm and field. Genotypic frequency of Benzimidazole resistance varies from $53 \%$ to $85 \%$. Resistant population is present at organized as well as private farms; it is showing higher resistance in organized farms which may be due to continuous use of Benzimidazole group of drugs.

\section{Author's contributions}

$\mathrm{AP}$ and MS has designed and supervised the research. SC collected samples and carried out experiment. NY and SD participated in coproculture. All authors read and approved the final manuscript.

\section{Acknowledgements}

The authors are highly thankful to Indian Council of Agricultural Research (ICAR) for funding through network programme on gastrointestinal parasitism and Director, Indian Veterinary Research Institute for providing facilities for research.

\section{Competing interests}

The authors declare that they have no competing interests.

\section{References}

1. Kumar, P., Malik, S., Kumar, N., Mehra, R. And Bhunyan, M. (2012) Acute and subacute toxicity studies of Mannich bases of Benzimidazole derivatives. Int. J. of Pharma.Sci. 1(2): 94-10

2. Kwa, M. S., Veenstra, J. G. and Roos, M.H. (1994) Benzimidazole resistance in $H$. contortus is correlated with a conserved mutation at amino acid 200 in -tubulin isotype-1. Mol. Biochem. Parasitol. 63:299-303.

3. Coles, G. C., Bauer, C., Borgsteede, F.H.M. and Geerts, S. (1992) World Association for Advancement Veterinary Parasitology (WAAVP) methods for the detection of anthelmintic resistance in nematode of veterinary importence. Vet. Parasitol. 44: 35-44.

4. Chandrawathani P., Premaalatha B., Nurulaini R., Erwanas AI., Zaini CM., Aizan M., Ramlan M. and Khadijah S. (2013) Severe Anthelmintic Resistance in Two Free Grazing Small holder Goat Farms in Malaysia. J. Vet. Sci. Technol., 4: 419.

5. Van den Brom, R., Moll, L., Borgsteede, F.H.M., Van Doorn, D.C.K., Lievaart-Peterson, K., Dercksen, D.P., and Vellema, P. (2014) Multiple anthelmintic resistance of Haemonchus contortus, including a case of moxidectin resistance, in a Dutch sheep flock. Vet. Rec., 173 (22): 552.

6. Roos, M. H., Kwa, M. S. G. and Grant, W. N. (1995) New genetic and practical implications of selection for anthelmintic resistance in parasitic nematodes. Parasitol. Today. 11: 148-150.

7. Varshney T.R. and Singh, Y.P. (1976). A note on development of resistance of $H$. contortus worms against phenothiazine and thiabendazole in sheep. Indian J. Anim. Sci. 46: 666-668.

8. Uppal, R.P., Yadav, C.L., Godara, P. And Rana, J.S., (1992) Multiple anthelmintic resistance in a field strain of $H$. contortus in goats. Vet. Res. Commun., 16: 195-198.

9. Yadav, C.L., Ghorui, S.K., Singh, B.P. and Sharma, M.C. (1996) Benzimidazole resistance in $H$. contortus of sheep and goats in Uttar Pradesh. J. Vet. Parasitol. 10: (1) 47-51.

10 Sankar, M. (2003) Studies on benzimidazole resistance in $H$. contortus in sheep.M.V.Sc thesis submitted to Deemed University Indian Veterinary Research Institute.

11. Sankar, M. (2007) Molecular characterization of $\beta$-tubulin gene in benzimidazole resistant and susceptible populations of common gastrointestinal nematodes in small ruminants. 
Ph.D thesis submitted to Deemed University, Indian Veterinary Research Institute.

12. Ram, H., Rasool, T.J., Sharma, A.K., Meena, H.R.and Singh, S.K. (2007) Comparative efficacy of different anthelmintics against fenbendazole resistant nematodes of pashmina goats. Vet. Res. Commun., 31(6): 719-923.

13. Garg, R. and Yadav C.L. (2009) Genotyping of benzimidazole susceptible and resistant alleles in different populations of Haemonchus contortus from Himalayan and sub-Himalayan regions of North-West India. Trop Anim Health Prod. 41:1127-1131.

14. Maharshi, A.K., Swarnkar, C.P., Singh, D. and Mahonar, G.S. (2011) Correlation between status of benzimidazole resistance in Haemonchus contortus on bio and molecular assays. Indian J. Anim. sci., 81:110-115.

15. Easwaran, C., Harikrishnan, T.J. and Raman, M. (2009) Multiple anthelmintic resistance in gastrointestinal nematodes of sheep in Southern India. Vet. Arhiv. 79: 611-620.

16. Jeyathilakan, N., Radha, G., Gomathinavagam, S. and John,
L. (2013) Emergence of anthelmintic resistance in G.I nematodes of sheep in Tamil Nadu. J. Vet. Parasitol. 17(2): 159-160.

17. Van Wyk, J.A. and Mayhew, E. (2013) Morphological identification of parasitic nematode infective larvae of small ruminants and cattle: A practical lab guide. Onderstepoort $J$. Vet. Res. 80(1):1-14.

18. Sambrook, (2001) Molecular cloning (Cold Spring Harbor Laboratory Press, New York) $3^{\text {rd }}$ edition:6.4-6.12.

19. Silvestre, A., and Humbert, J.F. (2000) A molecular tool for species identification and benzimidazole resistance diagnosis in larval communities of small ruminant parasites. Exp. Parasitol. 95:271-276.

20. Snedecor GW. and Cochran WG. (1994) Statistical Methods, (lowa University Press, lowa, U.S.A.), $8^{\text {th }}$ edition: 74.

21. Tiwari, J., Kumar, S., Kolte, A.P., Swarnkar, C.P., Singh, D. And Pathak, K.M. (2006) Detection of benzimidazole resistance in Haemonchus contortus using RFLP-PCR technique. Vet. Parasitol. 138(3-4):301-307.

$* * * * * * * *$ 